\title{
A modeling assessment of geneflow in smallholder agriculture in West Africa
}

Denis Worlanyo Aheto ${ }^{1 *}$, Hauke Reuter ${ }^{2}$, Broder Breckling ${ }^{3}$

\begin{abstract}
Purpose: Small-scale agriculture is an important issue for food security in Africa. In the context of Genetically Modified Organisms, approaches to quantify geneflow in small-scale systems are widely unexplored. We aimed at bridging this gap by contributing to the scientific discussion on the uncertainties of the cultivation of genetically modified (GM) crops in the region. The safety issue is: Would it be possible to withdraw a variety in case that unexpected and undesirable effects occur? e.g. the resistance of pests which make the variety no more useful.

Methods: We used a GIS approach to determine the location of maize cultivation sites, field geometries and applied a model for the calculation of geneflow scenarios.

Results: The data revealed that the given cropping density provides optimal conditions for transgene spread, potentially limiting the possibility for coexistence between GM and non-GM fields. On average, we found about 60 fields within a nearest distance of $100 \mathrm{~m}$, and cropping density of 56 fields per square kilometer. The resulting cross-pollination rate from the single GM field into the neighbouring conventional fields was estimated to be about $0.12 \%$.

Conclusions: GM varieties if introduced could remain in cultivation even if their admission has expired or has been retracted. This would be undesirable and could cause long-term, undesirable stacked combination of transgenes which cannot be tested with respect to eventual combinatory effects. These developments pose major challenges for fielder livelihoods, and conservation of maize genetic resources with potentially negative consequences for the African food export sector.
\end{abstract}

\section{Purpose}

In spite of an obvious need, few studies exist focusing on biosafety research in Africa. This paper therefore presents an account of a project that assessed the implications of Genetically Modified Organisms (GMOs) in small-scale agricultural systems in Africa by focusing on a specific sector of agricultural food production in Ghana. Maize cultivation has been used in this instance to distinguish the differences that exist between agriculture in the USA or Europe, and elsewhere in other developed countries and those of the African conditions; in particular, looking at the agricultural structure, crop field locations, isolation distances between cultivated fields and spatial patterns of agricultural fields which are completely heterogeneous. On the basis of a modelling

\footnotetext{
* Correspondence: worlaheden@yahoo.com

${ }^{1}$ School of Biological Sciences, Science Faculty Building, University Post office, University of Cape Coast, Ghana.

Full list of author information is available at the end of the article
}

approach, representative scenarios are calculated to address the possible impacts of gene flow between genetically modified (GM) and conventional fields due to cross-pollination.

We use the situation of agricultural maize production in Ghana to typify the situation of subsistence-based fielding context in West Africa which is the predominant mode of fielding as opposed to a very minor proportion that occur as large-scale commercial fielding enterprises. Agricultural land area in Ghana estimates to about $58.3 \%$ of total land area of 24 million hectares. Individual field sizes measure between 1 and 2 ha [1]. Within these land holdings, maize represents the major food crop cultivated, since it constitutes the major food staple for a majority of the population [2]. Maize is often grown in association with other crops. However, the demand for maize in particular as a major food source in the country has led to the observed annual increase in acreage of land grown to maize (Figure 1)

\section{SpringerOpen ${ }^{\circ}$}

(C) 2011 Aheto et al; licensee Springer. This is an Open Access article distributed under the terms of the Creative Commons Attribution License (http://creativecommons.org/licenses/by/2.0), which permits unrestricted use, distribution, and reproduction in any medium, provided the original work is properly cited. 


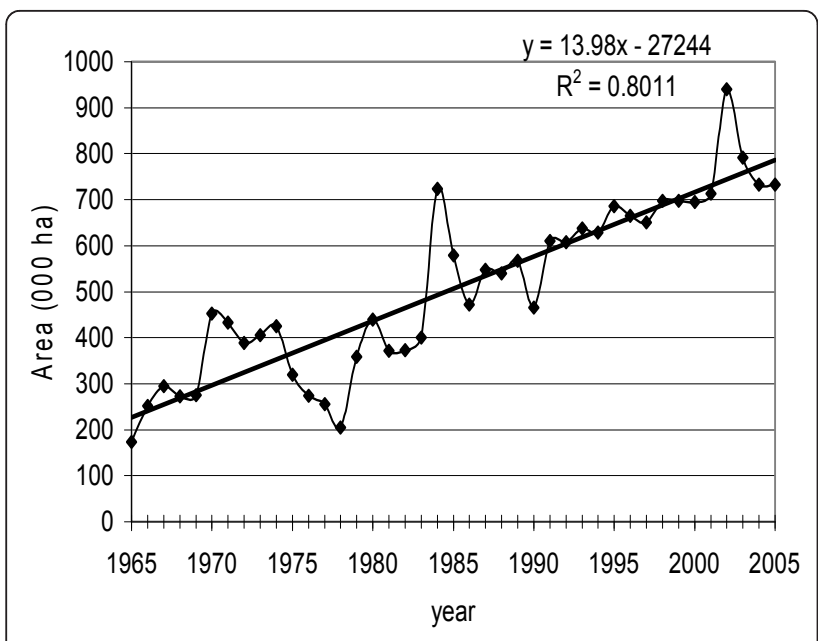

Figure 1 Maize production in Ghana (1965-2005) showing area of land grown to maize over the period. Source: Calculated from FAO database (2007); and Morris et al. (1999) Adoption and Impacts of Improved Maize Production Technology: A Case Study of the Ghana Development. Project. Mexico, D.F.: CIMMYT.

$[3,4]$. Therefore, acreage of land sown to maize has steadily increased into the overall agricultural land area. Field surveys have revealed that fielders mostly sow fractions of grains bought for food, or seeds saved from previous harvests, obtained as gifts from other fielders, exchanged or simply procured through the formal seed system mainly from seed shops [5]. In the context of land use, the increasing intensity of maize cultivation coupled with the complexities of seed use and exchange has made the discussion on GMOs highly contentious. The situation is largely constrained because regional markets for GMOs are being developed in Africa. Profits and progress are promised in view of a new wave of growth for the agricultural sector in the region [6]. In this regard, GMOs are advertised as an option in support of poverty and hunger alleviation and to feed poor countries in the region [6-8]. Alongside these developments, serious concerns exist relating to the long-term economic benefits of the technology to small fielders. Questions are being asked about who benefits and who appropriates? Consequently, African states would be in the position to invest huge expenditures to redress environmental damages on the numerous and spatially disaggregated small fields if negatively impacted upon and the resulting public health consequences if adverse effects emerge [9]. For example, setting up huge GMO testing facilities at ports of entry comes at additional costs to government that must be well taken into account in advance.

There are also concerns about the unclear nature of the use of genetic resources in the advent of GMO and related issues of patenting and biopiracy since small traditional fielders would like to benefit from their many years of sustaining seed biodiversity maintained over centuries [5]. There is the fear of a high possibility of transgene escape if grain is used as seed, assumed likely under the present agricultural circumstances given the traditional seed exchange and utilization culture [10]. These issues are discussed as legitimate concerns in this context since maize is widely used as food in Africa, with the crop representing the largest component of food for the greater segment of the African population.

It is also noteworthy that elsewhere in the world, the deployment of GM maize has practically caused widespread environmental, economic and legal problems [11]. For example, there have been events of genetic contamination by transgenes in managed non-transgenic conventional production fields in Mexico [12]. Again, GM pollen with insect resistance may pose potential hazard to non-target insect species as has been reported by several authors [13-15]. As far as regulation is concerned, it has been argued that though various acts and regulations are in place in some African countries and are supposed to be implemented, there is no formal system to verify the GM content of trans-boundary consignments, save for the permission of permits. The regulation of mandatory labelling of GMOs is inactive and there is no provision for GMO labelling in terms of consumer preference [16].

Owing to the aforementioned complexities of seed use or exchange practices, agricultural structure, increasing land use and maize cultivation intensity, weak regulatory and enforcement capacity in African countries, the safety issues refer to whether it would be feasible to recall a GM variety in case the unexpected happens. For example, with an occurrence of undesirable effects such as the resistance of pests which make the variety no longer useful.

In order to contribute to the scientific discussion, our study sought to calculate geneflow assessment of crosspollination rates under various scenario assumptions of maize cultivation, and calculate field neighbourhood distance relations and estimate general field geometries. These parameters have been intended to contribute to improvements for biosafety assessment at the local level and support the institution of precautionary measures according to the Cartagena Protocol on Biosafety [17] referring to Art. 1, 10, 11 and Annex III) that enjoins sovereign states or governments to take precaution and extended to cover other contextual issues including aspects of receiving environments and not only on the basis of existing knowledge. The specific objectives of the study were to:

1. Use geographic information system (GIS) to characterize crop fields to assess their distribution and isolation distances. 
2. Conduct frequency and cropping density analysis to assess feasibility of coexistence measures.

3. Simulate regional cross-pollination to determine potential for geneflow in smallholder systems following a modeling approach.

We hypothesize that smaller cultivated fields and higher heterogeneity of the seed sources implicitly lead to an increased geneflow and increased genetic exchange in the longer term. This is a preliminary study in which minimal baseline scenarios have been used relevant for biosafety assessment for African agriculture taking into account an African environmental perspective.

\section{Methods}

The study was carried out within a peri-urban district of Accra, the capital city of the Republic of Ghana. The methods used had been adapted to the Ghanaian agricultural and environmental conditions based on other works [18]. Data on spatial orientation of crop fields (see Table 1 ) in a $25-\mathrm{km}^{2}$ region were determined using a global positioning system (GPS) receiver, and later systematized through a GIS database using ArcGIS. Cross-pollination was not measured directly but potential gene flow was assessed by applying a model-based analysis process. Analysis of cross-pollination studies [19-28] and the subsequent development of a dispersal kernel had been done (Figure 2) [29] describing crosspollination relative to source-sink-distance and fieldsize. This dispersal-kernel was applied in simulations to calculate cross-pollination between maize fields. As the model uses simplified geometric structures, it may be applied for whole regions. The model was developed largely for European conditions within the GeneRisk Project funded in the context of the Social Ecology Call in
2008 (http://www.sozial-oekologische-forschung.org/en/ 692.php). The relevant data to parameterise the model for the Ghanaian conditions include field maps, variability in the sowing dates, the vegetative period, duration of pollination and maximum distance of dispersal. Isolation distances from field neighbours were calculated using computer programs written in SIMULA [30].

Five (5) scenarios were assessed, implying that genetic modifications (GM) or transgenes get introduced through mode of seed acquisition and via larger fields as follows:

- Scenario 1: GM seeds sown were obtained under exchange conditions, meaning that the seeds were obtained from other fielders as gifts or exchanged.

- Scenario II: GM seeds sown were obtained from the seed market. This directly implies the use of commercial GM varieties.

- Scenario III: A single GM field introduced at the center of the study area. This suggests the scenario of a single GM field among 1,388 conventional fields.

- Scenario IV: GM seeds sown were obtained from seeds saved from previous harvests.

- Scenarion V: GM seeds sown were obtained from food market. This scenario implies that variety planted was collected from quantities bought for food.

The model was run 10 times per scenario and average calculations written to an output file (see Table 4).

\section{Results}

\section{Cropping density and field geometry}

Table 2 provides an overview of the cultivation context as obtained from GIS records for the area of $25 \mathrm{~km}^{2}$ in peri-urban Accra.

Table 1 Ground surface data based on GPS measurements

\begin{tabular}{|c|c|c|c|}
\hline $\begin{array}{l}\text { Sample } \\
\text { number }\end{array}$ & Variable & Descriptors & Assignments \\
\hline \multirow[t]{2}{*}{1} & $\begin{array}{l}\text { Field } \\
\text { locations }\end{array}$ & $\begin{array}{l}\text { Specification of single locations of field allotments based on GPS } \\
\text { readings of first point of entry of the cultivation area referred } \\
\text { herein as field. }\end{array}$ & $\begin{array}{l}\text { For estimating minimum distance between fields. This } \\
\text { is an important parameter for estimating the } \\
\text { probability of gene (pollen) transfer from genetically } \\
\text { modified to conventional maize fields (or vice versa). }\end{array}$ \\
\hline & & & $\begin{array}{l}\text { This is also useful to estimate the length of field } \\
\text { borders. }\end{array}$ \\
\hline 2 & Field sizes & $\begin{array}{l}\text { Estimation of total acreage of fields - measurements taken at } \\
\text { corners of the cultivation area ranging from 3-22 corners, } \\
\text { depending on field extent. }\end{array}$ & $\begin{array}{l}\text { Mean field size gives information on the dispersal } \\
\text { characteristics of the cultivation area. }\end{array}$ \\
\hline
\end{tabular}
depending on field extent.

The spreading of pollen is more likely in regions with large number of smaller fields than in regions with fewer larger fields.

Feral/ Specification of precise location points within same habitat patch. For estimation of nearest neighbour relations.
volunteer
locations



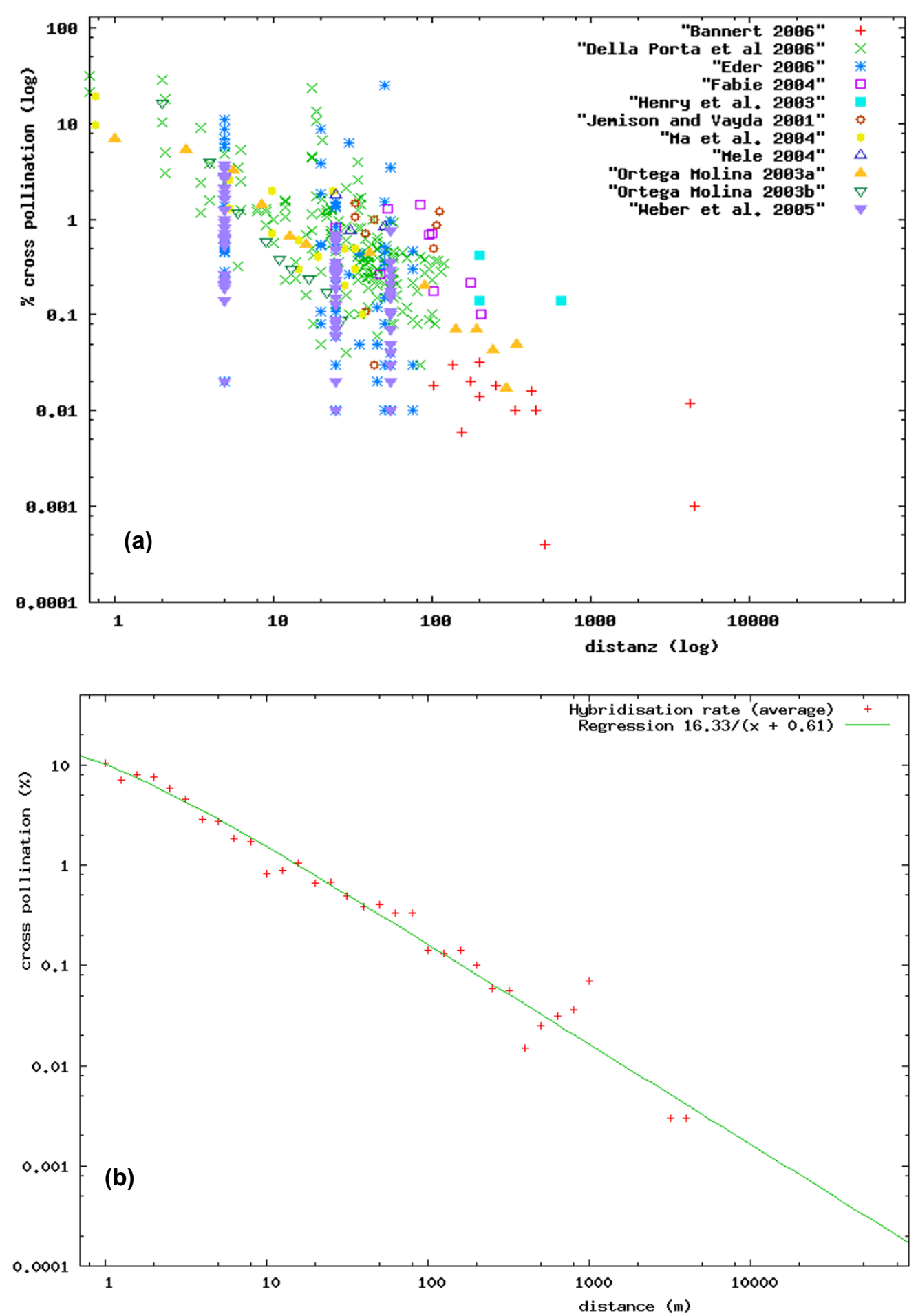

Figure 2 Analyzed cross-pollination studies. Literature studies on distance-related out-crossing rates in hybrid maize fields (a) used for the development of the dispersal kernel (b), projected on a double logarithmic scale. The data shows a regression function with a gradual reduction in hybridization rates from $0.14 \%$ at $100 \mathrm{~m}, 0.1 \%$ at $200 \mathrm{~m}$, and $0.06 \%$ at $250 \mathrm{~m}$ and about $0.01 \%$ at over 1,000 $\mathrm{m}$. The displayed references in (a) are quoted in the reference list. The data of Ortega Molina (2003a) and (2003b) were republished in 2004. 
Table 2 Cropping density factors of maize fields in the study area

\begin{tabular}{lc}
\hline Item & Description \\
\hline Cropping density (number of fields $\mathrm{km}^{-2}$ ) & 56.0 \\
\hline Total maize area calculated from GlS records $\left(\mathrm{km}^{2}\right)$ & 1.1 \\
\hline Fractional area of maize as a \% of total study area & 4.5 \\
\hline \% Field sizes below 0.5 ha & 97.4 \\
\hline \% Field sizes between 0.5-1 ha & 1.6 \\
\hline \% Field sizes between 1-2 ha & 0.8 \\
\hline \% Field sizes above 2 ha & 0.2 \\
\hline
\end{tabular}

Total number of fields was 1,390 .

For an urban settlement area, a 4.5\% fractional area grown to maize is significant. The incorporation of GM varieties could impact highly on the agrifood sector of traditional maize cultivation. In Figure 3, about 98\% of all field locations occur within distance of 5-150 m from the next neighbour. Shortest nearest distance from next neighbour recorded occurred within $5 \mathrm{~m}$. Longest nearest distance occurred at a distance of $459 \mathrm{~m}$.

Table 3 shows that there are up to a maximum of three field neighbours on average within a distance of $20 \mathrm{~m}$, and up to a total maximum of seven field neighbours within a distance of $40 \mathrm{~m}$. A maximum of 38 field neighbours occur within a $120 \mathrm{~m}$ distance.

Figure 4 shows that even though fields are very small in size (mostly approximately $<2$ ha), considerably large areas are grown to maize. Fields cultivated in the region occur irregularly and widespread on the landscape. There are indications of boundary segments of only about $1 \mathrm{~m}$ occurring between some adjacent fields. It
Table 3 Cropping isolation distances of field neighbours

\begin{tabular}{cc}
\hline \multicolumn{2}{c}{ Number of field neighbours within distance ranges } \\
\hline Distances $(\mathbf{m})$ & Mean (maximum number of fields) \\
\hline $0-20$ & $0.2(3.0)$ \\
$20-40$ & $0.6(4.0)$ \\
$40-60$ & $0.8(5.0)$ \\
$60-80$ & $1.0(7.0)$ \\
$80-100$ & $1.1(8.0)$ \\
$100-120$ & $1.4(11.0)$ \\
\hline
\end{tabular}

appears therefore that the small-scale fields do not follow a purely managed cultivation pattern. The data explains that neighbouring fields could have high crop population and cross-pollination interaction rates. Many small fields occur in the vicinity of a larger field, suggesting potentially higher cross-pollination from larger fields to neighbouring smaller fields.

Figure 5 provides indication of high cropping densities involving many small fields, randomly distributed over the landscape. The data shows that the cultivation of fields is highly irregular, and often occurring in association with one another.

\section{Simulations of regional cross-pollination}

The simulation was primarily based on GPS-derived maps indicating locations of crop fields where fielders planted seeds acquired on exchanges from other fielders and contrasted with those locations where fielders planted seeds bought from the seed market. Model calculations are further analyzed for additional scenarios executed for different potential situations that could occur (Table 4).

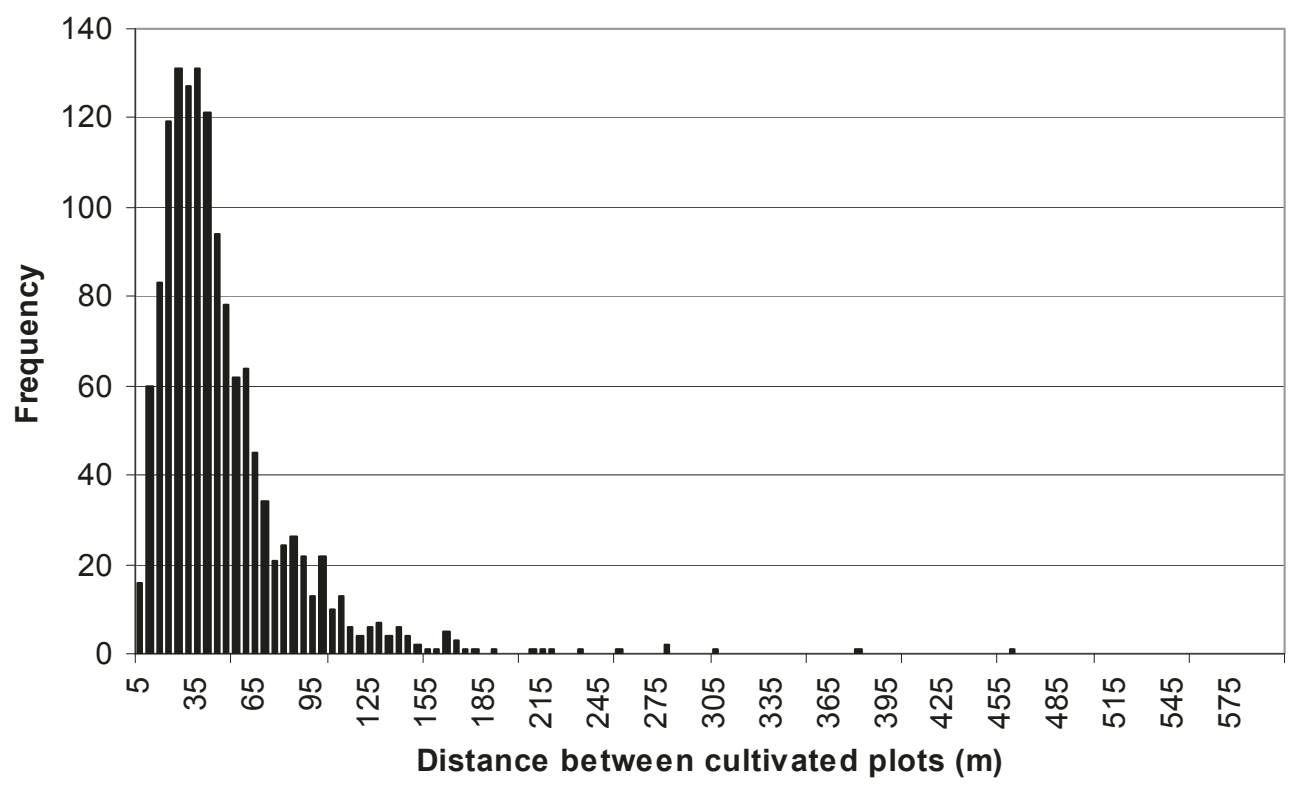

Figure 3 Nearest neighbour distance analysis of crop fields. 
Table 4 Assessment of potential impacts of geneflow based on various seed sources using the MaMo

\begin{tabular}{|c|c|c|c|}
\hline \multirow[b]{2}{*}{ Modelling Scenarios } & \multicolumn{3}{|c|}{ Maize hybrids } \\
\hline & $\begin{array}{l}\text { Average GM } \\
\text { content in } \\
\text { conventional seed } \\
\text { harvest }\end{array}$ & $\begin{array}{l}\text { GM fields created as a } \\
\text { percentage of total number of } \\
\text { fields (including conventional } \\
\text { fields) }\end{array}$ & $\begin{array}{l}\text { GM field area estimated as a } \\
\text { percentage of total field area } \\
\text { (including conventional fields) }\end{array}$ \\
\hline $\begin{array}{l}\text { Scenario I: GM planted was obtained under } \\
\text { exchange conditions, meaning that the seeds were } \\
\text { obtained from other fielders as gifts or exchanged. }\end{array}$ & 0.87 & 3.02 & 2.27 \\
\hline $\begin{array}{l}\text { Scenario II: GM planted were obtained the seed } \\
\text { market. This directly implies the use of commercial } \\
\text { varieties. }\end{array}$ & 2.61 & 7.70 & 6.02 \\
\hline $\begin{array}{l}\text { Scenario III: GM planted was obtained from seeds } \\
\text { saved from previous harvests. }\end{array}$ & 1.00 & 4.24 & 2.40 \\
\hline $\begin{array}{l}\text { Scenario IV: Single GM field introduced at the center } \\
\text { of the study area. This suggests the scenario of a } \\
\text { single GM field among 1,388 fields }\end{array}$ & 0.12 & 0.07 & 0.21 \\
\hline $\begin{array}{l}\text { Scenario V: GM planted obtained from food market. } \\
\text { This scenario implies that variety planted was } \\
\text { collected from quantities bought for food. }\end{array}$ & 1.12 & 2.52 & 3.78 \\
\hline
\end{tabular}

The single GM field scenario in conventional fields was introduced as a hypothetical issue.

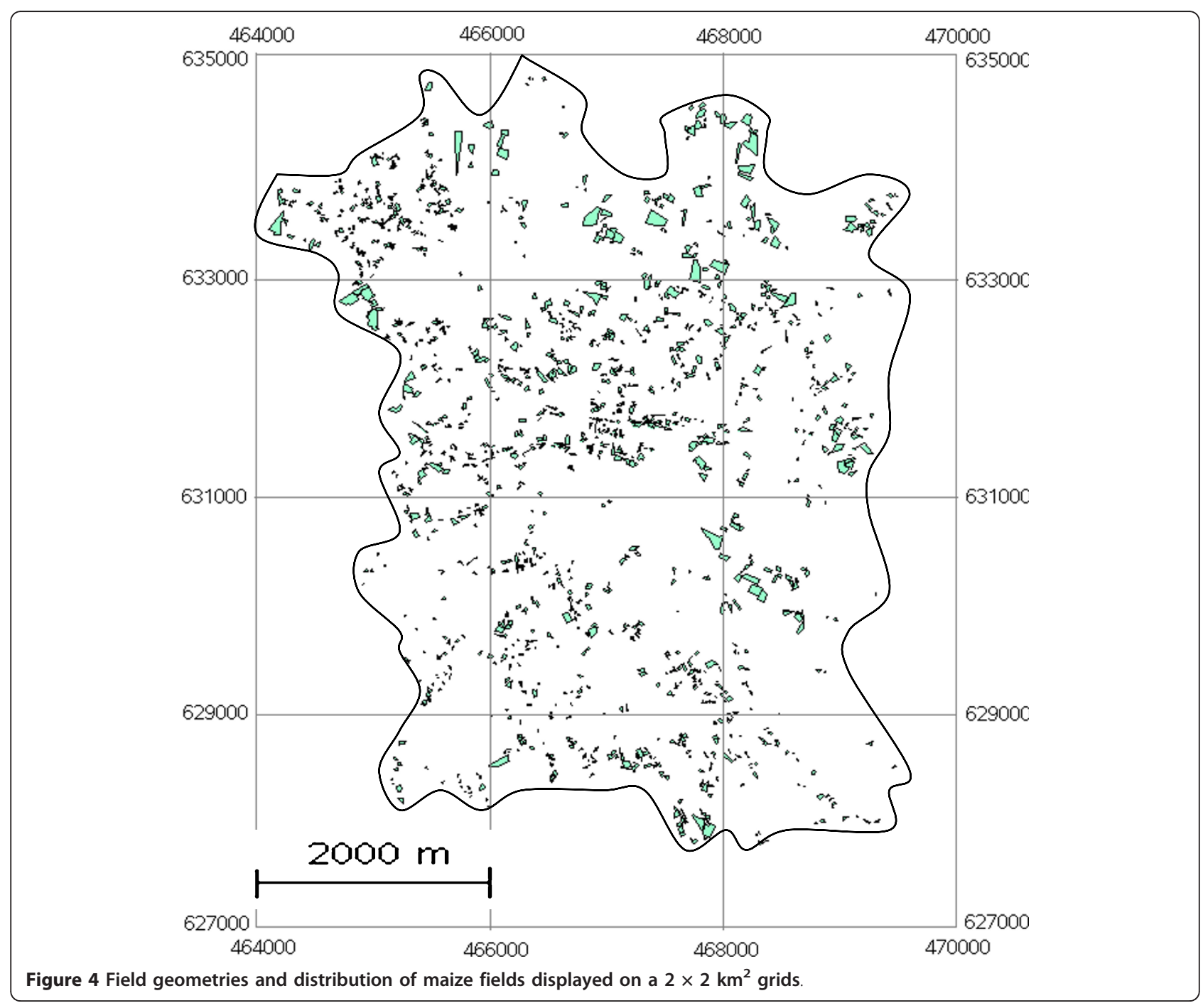




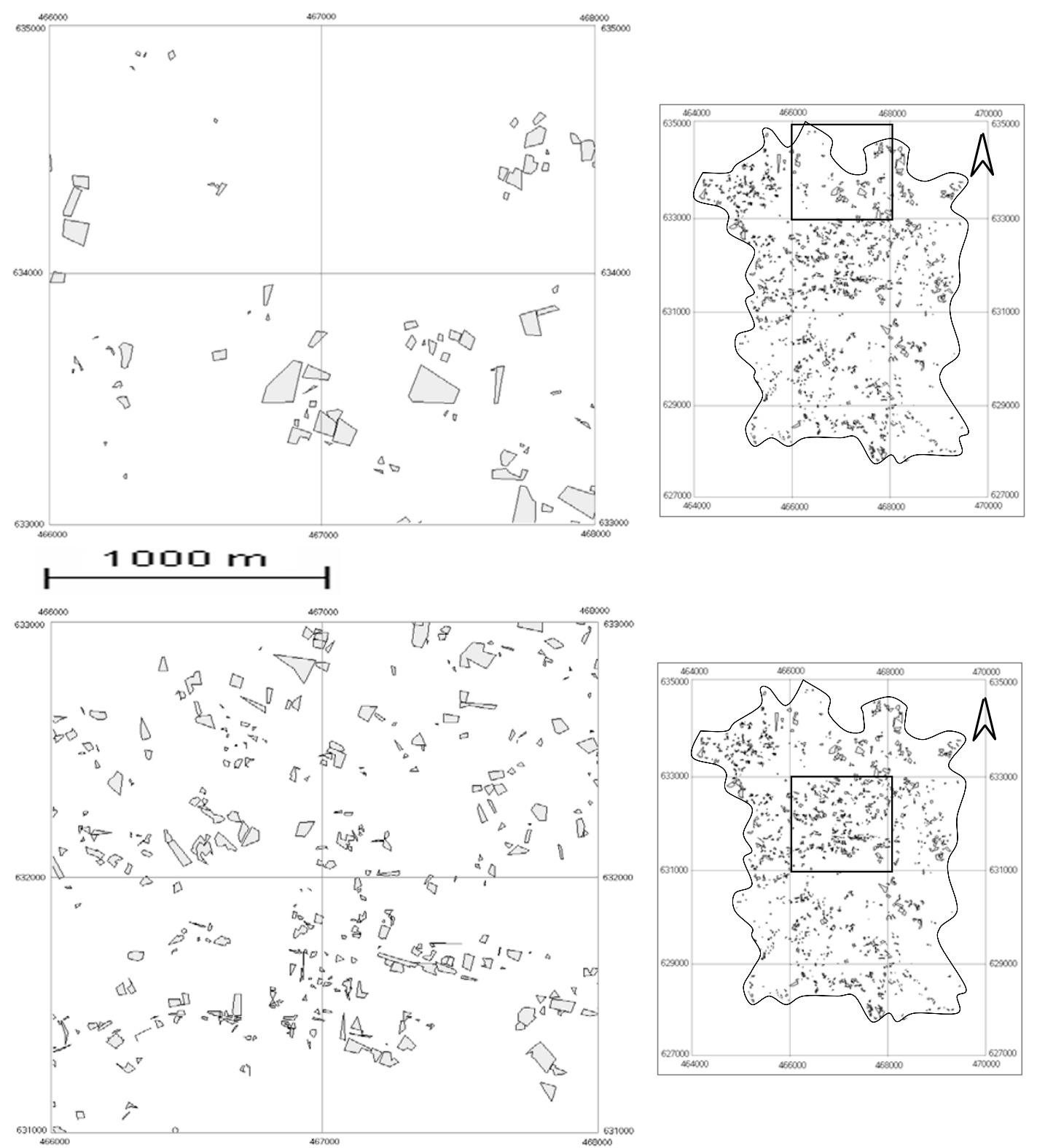

Figure 5 Cropping geometry and density analysis of smallholder maize agricultural systems. The maps provide examples of a higher number of smaller fields occurring in close association with larger fields suggesting higher probabilities of gene flow from larger fields to smaller fields. In addition, high cropping density regions suggest the growing of different maize seed varieties with indications of seed exchange and admixture among fielders. The entire region investigated is shown on the right hand maps.

This allows to estimate the effects resulting from not only for single GM central fields but also to consider the effects of random processes, how the entry of GM seeds obtained from food and seed markets or eventually from previous harvests could influence cross-pollination in conventional fields. The specification of field locations on maps for seed sources and type of seed cultivated was obtained through a questionnaire.

The model provides average cross-pollination rates basing on several world-wide studies capturing the variability in climate and environmental factors. A map was derived for all locations where seeds had been planted from: (a) exchange sources, (b) seed market and (c) and those obtained from previous harvests. The single GM central field (d) had been assumed in order to derive hypothetical scenario for the possible impacts of a single GM field, and (e) assuming that GM seeds planted were obtained from food market. This scenario implies that variety planted was collected from quantities bought for food (see Table 4). 


\section{Model Scenario 4: single GM field in the centre of the} study area

Modeling simulation with a single GM field located in the centre of the investigated region (circled). Each of the fields serves as a pollen source and calculates the impact to all other fields. It shows the involvement of random processes depending on size and location of fields as well as sowing time.

The resulting model data suggest that smaller fields provide conditions for enhancing transgene spread due to their very small nature and close proximity with each other (Figure 6) and geneflow between GM and conventional fields is generally high regardless the source of seed used or seed acquisition scenario (Table 4). Analysis from the model further shows that a conventional field at a distance and size of $300 \mathrm{~m}\left(200 \mathrm{~m}^{2}\right), 800 \mathrm{~m}\left(4,000 \mathrm{~m}^{2}\right)$ and $1500 \mathrm{~m}\left(10,000 \mathrm{~m}^{2}\right)$ from a single central GM field would have average cross-pollination rates of 4.5\%, 1.0\% and $0.5 \%$ respectively (Figure 7 ). This strongly suggests that cross pollination rates in conventional fields generally decreases with increase in field size and distance to the GM field and vice-versa.

\section{Conclusions}

\section{Agro-structure and coexistence considerations}

The data show that the use of isolation distances between GM and conventional fields as a management measure or requirement to minimize or control gene flow is challenged in the given conditions. Most fields are small, with about $97 \%$ of fields below 0.5 ha (Table 2), occurring in very close proximity (Figure 3 ). For example, on a scale of $100 \mathrm{~m}$, a maximum of three, four, five, seven and eight field neighbours would have to be expected at distances of 20, 40, 60, 80 and $100 \mathrm{~m}$, respectively (Table 3 ). With a minimum nearest neighbour distance of $5 \mathrm{~m}$ and a maximum nearest distance of $459 \mathrm{~m}$ (Figure 3), the practice of co-existence of GM and conventional cropping would not be possible. In an event of GM introduction, on-field conservation of maize genetic resources is unlikely due to potentially higher cross-pollination in smaller fields (Figure 5). These findings coincide with studies conducted in Brazil [31] e.g. setting of a minimal isolation distance for coexistence for maize fields would be impractical. Hence, the usefulness of isolation distances under the given conditions is challenged. We conclude therefore that the hypothesis that for smaller cultivated fields and higher heterogeneity of the seed sources implicitly lead to increased geneflow and increased genetic exchange holds true.

\section{Cross-pollination scenarios and implications for gene flow}

The size of a recipient field, its location and the distance to a GM field are important parameters to estimate the probability of transgene introgression. For example, a single

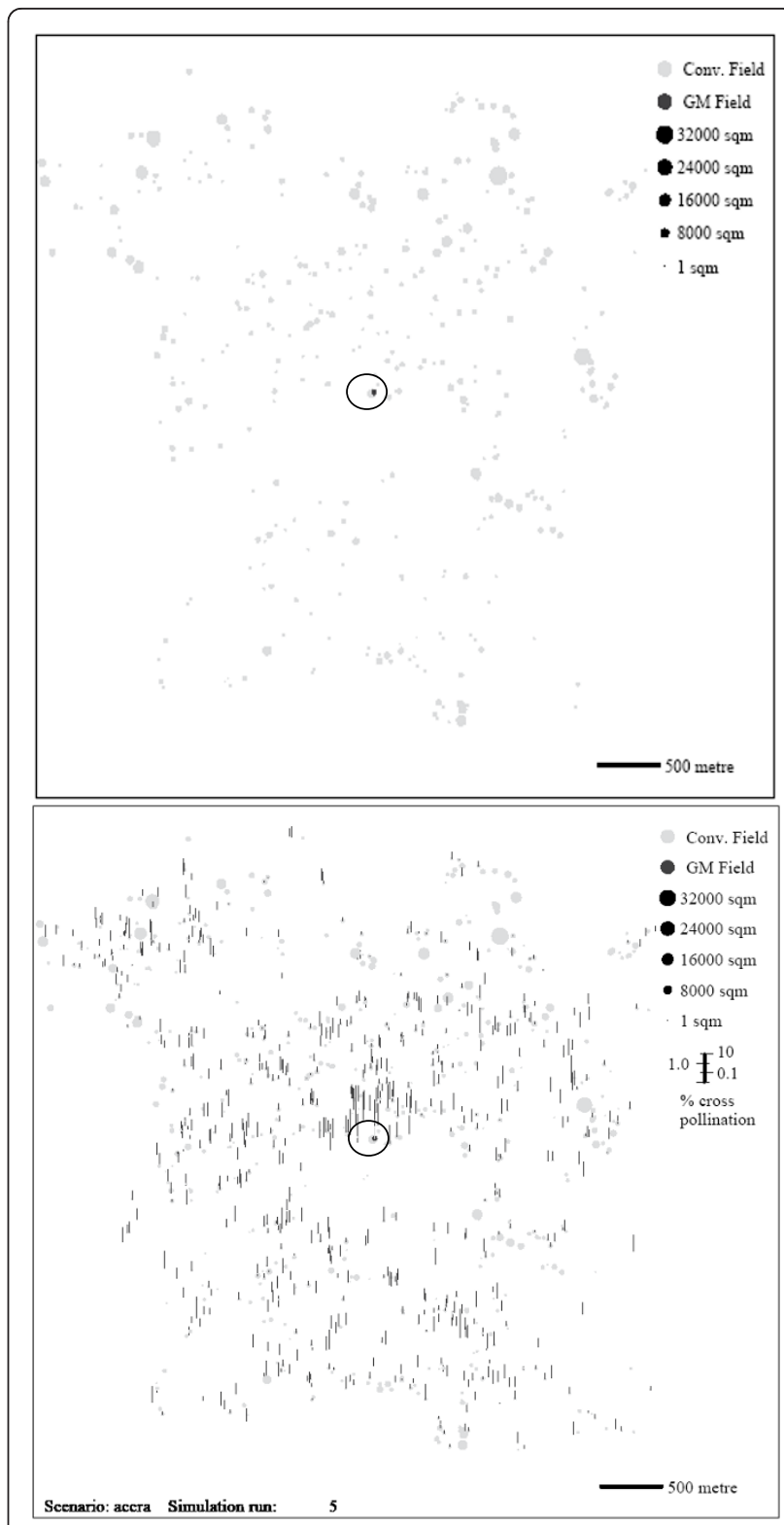

Figure 6 Model simulation of a single GM central field among over 1,300 conventional fields. (a) Shows the initial map with centre field (circled) (b) Shows the results of cross-pollination rates of the fields. There are some conventional fields that do not receive any GM input even though they occur in close association with the GM field, due to the effect of different sowing dates, and the fact that pollination times do not overlap. Random processes involved in pollen movement are incorporated in the model.

GM field was used as a minimum scenario (Figure 6). It turned out that a single GM field comprising $0.2 \%$ of the area could lead to gene flow in the considered region up to $0.12 \%$ of GM in the conventional harvest. There are indications that small fractions of transgene introgression in the order of magnitude from $0.12-2.61 \%$ into conventional fields are possible under the various tested conditions (Table 3). If the EU regulations would apply for the 


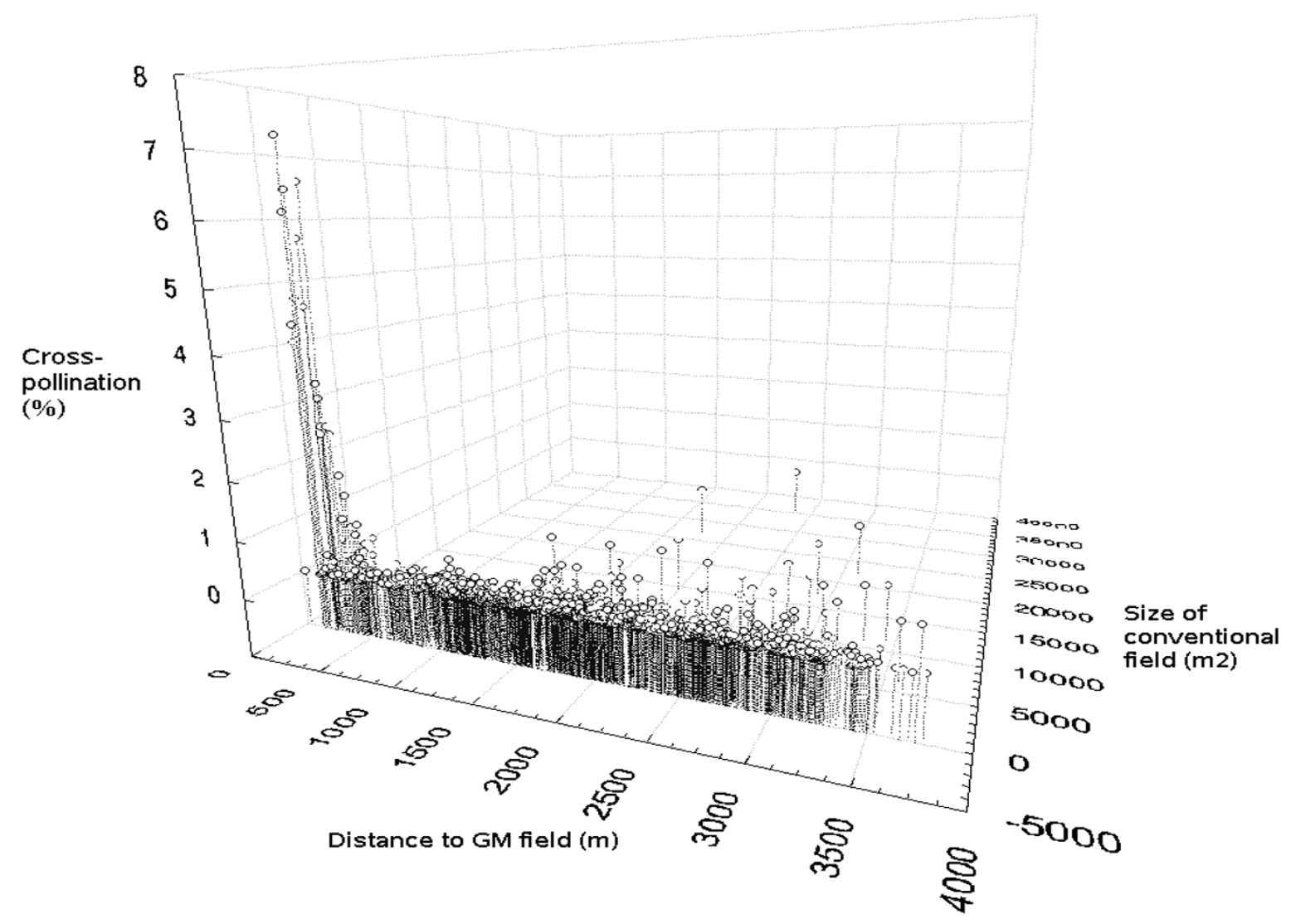

Figure 7 Cross-pollination rates of conventional fields. These are based on their sizes and distance to a single central GM source field. The data indicates that cross-pollination generally increases with a decrease in field size and distance to the single GM field and vice-versa.

African conditions at the same labeling threshold of $0.9 \%$, any increasing condition of transgene presence in conventional harvests from any magnitude above $0.9 \%$ is sufficient to be labeled and sold as GM. On-field conservation would be unlikely in an event of GM cultivation within small-scale agriculture due to increasing content of GM traits in field-saved seeds. Potentially, this would have severe consequences for the African food export sector and further deepen existing trade barriers afflicting the continent. For the reasons stated above, we recommend:

- the efficient regulation of maize grains used as food or feed products or even for seed imported into the country since it is highly unlikely to control transgene spread in the environment should they be later found out to be genetically modified varieties;

- to consider the cost implications for small fielder livelihoods and the additional cost to the local seed biodiversity that must well be taken into account.

We conclude that GMO maize should not be cultivated within the agricultural systems in Ghana and other West African countries with comparable agricultural conditions and efforts to introduce them should be curtailed.

\section{Acknowledgements}

The authors would like to thank Mr. Christian Aden formerly of the Department of Landscape Ecology of the University of Vechta, Germany for support with the GIS approach.

\section{Author details}

${ }^{1}$ School of Biological Sciences, Science Faculty Building, University Post office, University of Cape Coast, Ghana. ${ }^{2}$ Leibniz Center for Tropical Marine Ecology (ZMT), Fahrenheitstr. 6, 28359 Bremen, Germany. ${ }^{3}$ Department for Landscape Ecology, University of Vechta, Oldenburger Str. 97, 49377 Vechta, Germany.

\section{Authors' contributions}

DWA: Conceived the study, conducted field surveys in Ghana, handled data analysis, write-up and coordination. HR: Developed the maize model that was applied in this study in cooperation with $\mathrm{BB}$ and discussed the findings. BB: Participated in the design of the study, wrote programmes in SIMULA for handling large spatial data sets and supported data supervision and interpretation issues.

\section{Competing interests}

The authors declare that they have no competing interests.

Received: 23 January 2011 Accepted: 25 February 2011 Published: 25 February 2011

\section{References}

1. Al-Hassan R, Jatoe JBD: Adoption and Impact of Improved Cereal Varietie in Ghana. Paper prepared for the Workshop on the Green Revolution in Asia and its Transferability to Africa Tokyo, Japan; 2002 [http://www.fasid.or.jp/ chosa/forum/fasidforum/ten/fasid10/dl/2-7-p.pdf], FASID 8-10 Dec. 2002 Accessed on 5 June 2007. 
2. Fosu M, Kühne RF, Vlek PLG: Improving maize yield in the Guinea Savannah Zone of Ghana with leguminous cover crops and PK fertilization. Journal of Agronomy 2004, 3(2):115-121.

3. FAO: FAOSTAT. 2007 [http://faostat.fao.org/site/336/DesktopDefault.aspx? PagelD=336].

4. Morris LM, Tripp R, Dankyi AA: Adoption and Impacts of Improved Maize Production Technology: A Case Study of the Ghana Devlopment Project. Economics Programme Paper 99-01 Mexico, D.F.:CIMMYT; 1999.

5. Aheto DW: Implication Analysis for Biotechnology Regulation and Management in Africa. Baseline studies for Assessment of Potentential Effects of Genetically Modified Maize (Zea mays L.) Cultivation in Ghanaian Agriculture. Theory in Ecology 2009, 15:240.

6. ISAAA (International Service for the Acquisition of Agri-Biotech Applications): Global Status of Commercialized Biotech/GM Crops 2009. 2009 [http://isaaa.org/resources/publications/briefs/41/default.asp].

7. Walters R: Crime, Bio-Agriculture and Expploitation of Hunger. British Journal of Criminology 2005, 46(1):26-45.

8. African Center for Biosafety and Friends of the Earth Nigeria: Ten Years of Genetically Modified Crops Fail to Deliver Benefits to Africa. 2006 [http://www.organicconsumers.org/ge/africa011006.cfm].

9. African Union Commission: Compliance and Dispute Settlement Mechanisms for Biosafety. A publication series of the AU-German Cooperation Project "Support for the African Union on Issues of Biosafety". Addis Ababa: AUC Publishing and Reproduction Plant. 2009.

10. African Union Commission: Identification and labelling of living Modified Organisms (LMOs). A publication series of the AU-German Cooperation Project "Support for the African Union on Issues of Biosafety". Addis Ababa: AUC Publishing and Reproduction Plant; 2009.

11. Hewlett K, Azeez G: The economic impacts of GM contamination incidences on the organic sector. Proceedings of the Third International Conference on Coexistence between Genetically Modified (GM) and non-GM based Agricultural Supply Chains, 2007 November 20-21 Seville, Spain; 2007, 336-337.

12. Quist $D$, Chapela $॥ H$ : Transgenic DNA introgressed into traditional maize landraces in Oaxaca. Nature 2001, 414:541-543.

13. Aylor DE: Settling Speed of Corn (Zea mays) Pollen. Aerosol Science 2002, 33:1601-1607.

14. Losey JE, Rayor LS, Carter ME: Transgenic Pollen Harms Monarch Larvae. Nature 1999, 399:214.

15. Andow DA, Hilbeck A: Bt Maize, Risk Assessment and the Kenya Case Study In Environmental Risk Assessment of Genetically Modified Organisms. In A Case Study of Bt Maize in Kenya. Volume 1. Edited by: Hilbeck, A. Andow, D.A. Wallingford: CABI Publishing; 2004

16. Viljoen CD: Experiences and lessons learnt in the implementation of the identification/documentation requirements in the context of paragraph 2 of Article 18 of the Biosafety Protocol. Lessons from South Africa. Biosafety Protocol News 2007 Secretariat to the Convention on Biological Diversity, Montreal; 2007

17. Cartagena Protocol on Biosafety: Under the Convention on Biological Diversity, CBD. 2000 [http://www.biodiv.org/biosafety/protocol.shtml].

18. Menzel G: Verbreitungsdynamik und Auskreuzungspotenzial von Brassica napus L. (Raps) im Großraum Bremen-Basiserhebung zum Monitoring von Umweltwirkungen transgener Kulturpflanzen. Dissertation University of Bremen; 2006.

19. Bannert M: Simulation of transgenic pollen dispersal by use of different grain colour maize. Dissertation Eidgenössische Technische Hochschule Zürich 2006, Nr. 16508.

20. Della Porta G, Ederle D, Bucchini L, Prandi M, Pozzi C, Verderio A: Gene flow between neighboring maize fields in the Po Valley: a fact-finding investigation regarding coexistence between conventional and nonconventional maize fielding in the region of Lombardy, Italy.Edited by: Eder, J. Report, Centro Documentazione Agrobiotechnologie, Milan, Italy; 2006: [http://www.lfl.bayern.de], (2006) Bericht zum Erprobungsanbau mit gentechnisch verändertem Mais in Bayern 2005, Schriftenreihe der Bayrischen Landesanstalt für Landwirtschaft, Freising Weihstephan.

21. Eder J: Bericht zum Erprobungsanbau mit gentechnisch verändertem Mais in Bayern 2005, Schriftenreihe der Bayrischen Landesanstalt für Landwirtschaft, Freising Weihstephan. 2006 [http://www.lfl.bayern.de].

22. Fabie $A$ : Research on coexistence in the field. French experiments for maize. COPA COGECA Colloquy on the co-existence and thresholds of adventitious presence on GMOs In conventional seeds. 2004.
23. Henry C, Morgan D, Weekes R, Daniels R, Boffey C: Field scale evaluations of GM crops: monitoring gene flow from $\mathrm{Gm}$ crops to non-GM equivalent crops in the vicinity (contract reference EPG 1/5/138). 2003 [http://www.cib.org.br/estudos/estudos_cientificos_alimentar_14.pdf], Part I: Forage Maize. Final report, 2000/2003.

24. Jemison JM, Vayda ME Jr: Cross pollination from genetically engineered corn: wind transport and seed source. AgBioForum 2001, 4:87-92.

25. Ma BL, Subedi KD, Reid LM: Crop ecology, management \& quality. Extent of cross-fertilization in maize by pollen from neighboring transgenic hybrids. Crop Science Society of America 2004, 44:1273-1282.

26. Melé E: Spanish study shows that coexistence is possible. Agricultural Biotechnology International Conference ABIC 2004, 3:2.

27. Ortega Molina J: Results of the studies into the coexistence of genetically modified and conventional maize. COPA-COGECA colloquy on the coexistence and thresholds of adventitious presence on GMOs in conventional seeds. 2004 [http://www.copa-cogeca.be/pdf/9.pdf]

28. Weber WE, Bringezu T, Broer I, Holz F, Eder J: Koexistenz von gentechnisch verändertem und konventionellem Mais. mais - Die Fachzeitschrift für den Maisanbauer. 2005, Sonderdruck 1+2/2005.

29. Reuter H, Böckmann S, Breckling B: Analysing cross-pollination studies in maize. In Implications of GM-Crop Cultivation at Large Spatial Scales. Edited by: Breckling, B, Reuter H, Verhoeven R. Frankfurt, Peter Lang; 2008:47-53, Theorie in der Ökologie 14.

30. Pooley RJ: An introduction to programming in SIMULA, Blackwell Scientific. Oxford; 1986.

31. Cordeiro A, Alves AC, Ogliari J: Challenges for co-existence in small-scale fielding: the case of maize in Brazil. In Implications of GM-Crop Cultivation at Large Spatial Scales. Edited by: Breckling, B., Reuter, H. \& Verhoeven, R. Frankfurt, Peter Lang; 2008:, (2008) Theorie in der Ökologie 14.

doi:10.1186/2190-4715-23-9

Cite this article as: Aheto et al:: A modeling assessment of geneflow in smallholder agriculture in West Africa. Environmental Sciences Europe 2011 23:9.

\section{Submit your manuscript to a SpringerOpen ${ }^{\odot}$ journal and benefit from:}

- Convenient online submission

- Rigorous peer review

- Immediate publication on acceptance

- Open access: articles freely available online

- High visibility within the field

- Retaining the copyright to your article

Submit your next manuscript at springeropen.com 